\title{
Cerebral candidiasis : case report of brain abscess secondary to Candida albicans, and review of literature
}

\author{
JOSEPH T. BLACK \\ From the Department of Neurology, University of Miami School of Medicine, Jackson Memorial Hospital, \\ Miami, Florida, U.S.A.
}

SUMMARY A patient with a brain abscess due to Candida albicans is reported. This patient had three episodes of systemic candidiasis in spite of the fact that she had no underlying debilitating disease and had never received prior antibiotic or adrenocortical steroid therapy. A review of the literature reveals 42 cases of central nervous system Candida albicans infection. The salient features of these cases are tabulated and discussed. The clinical features, pathology, pathogenesis, treatment, and aetiology of cerebral candidiasis are also discussed.

Candida organisms are common saprophytes which reside on the skin and mucous membranes of the gastrointestinal tract in healthy persons, and in the vagina of pregnant and diabetic women. This fungus is ordinarily a weak pathogen which produces mild superficial infection, but occasionally it may cause a systemic disease with involvement of the lung, kidney, endocardium, brain, or reticuloendothelial system. In almost all instances of acute disseminated candidiasis the defence mechanisms of the host have been reduced by predisposing factors such as prior antibiotic therapy (Seelig, 1966), systemic adrenocortical steroids (Louria, Stiff, and Bennett, 1962), indwelling intravascular catheters (Louria et al., 1962), diabetes mellitus, and other serious chronic diseases. In addition, various neoplastic diseases such as lymphoma and Hodgkin's disease (Casazza, Duvall, and Carbone, 1966) favour the development of Candida infection and dissemination, but even in these diseases the development of systemic candidiasis was a rare event before modern therapy with bone marrow suppressants, antibiotics, steroids, and roentgen irradiation (Friedman, 1965).

A case report is presented of a patient afflicted with three episodes of systemic Candida albicans infection, the last of which primarily involved her central nervous system. All three episodes occurred without underlying debilitating disease and without prior antimicrobial or hormonal therapy. Previous reports of Candida albicans infection of the central nervous system are reviewed. In addition, the pathology, pathogenesis, treatment, aetiology, and clinical aspects of this and the other reported cases are discussed.

\section{CASE REPORT}

The patient was a 29 year old French Canadian woman who was in good health until September 1965 when she developed cervical lymphadenopathy. In November 1965 a cervical lymph node biopsy revealed Candida albicans for which she received approximately $1 \mathrm{~g}$ intravenous amphotericin B. She did well until May 1967 when she developed vaginal moniliasis, generalized lymphadenopathy, and an abdominal mass. A large abdominal lymph node was biopsied during exploratory laparotomy and amphotericin B was reinstituted after culture revealed Candida albicans. She received a total of $1.425 \mathrm{~g}$ amphotericin and by October 1967 she had no clinical evidence of the disease.

The patient had been pregnant four times during which she never developed vaginal moniliasis. A review of the family history revealed that none of her family had frequent or bizarre infections.

In August 1968 she was seen for the first time by the author. She was two months pregnant but otherwise asymptomatic. Physical examination, radiographs of the chest, and liver function tests were normal.

On 5 February 1969 the patient had a grand mal seizure and physical examination one hour later revealed her to be disorientated and somnolent. A uterus consis tent with a $8 \frac{1}{2}$ month pregnancy was felt on abdominal examination, but vaginal moniliasis was not present. The remainder of the physical examination disclosed no abnormalities. Laboratory data including haematocrit, haemoglobin, total and differential white blood count, 
urinalysis, serum electrolytes, calcium, phosphorus, blood urea nitrogen, liver function tests, and five hour glucose tolerance test were normal. A lumbar puncture showed an initial pressure of $120 \mathrm{~mm} \mathrm{H}_{2} \mathrm{O}$ with a cell count of 1 lymphocyte/c. mm, and glucose content of 56 $\mathrm{mg} / 100 \mathrm{ml}$. No fungus or bacteria grew in the cerebrospinal fluid cultures. An electroencephalogram was normal. No other neurological procedures were attempted because of the patient's pregnancy. Several days after admission she delivered a healthy, $6 \mathrm{lb} .7 \mathrm{oz}$. $(2 \cdot 9 \mathrm{~kg})$ female child who had no evident vaginal or cutaneous moniliasis.

On 6 March 1969, the patient developed spontaneous paraesthesias and involuntary clonic movements of the right arm and right side of the face. There was no associated loss of consciousness, although the focal seizure lasted two hours.

PHYSICAL EXAMINATION The patient was a well-developed well-nourished woman with a normal blood pressure and pulse rate. Both buccal and vaginal moniliasis were present, but she had no lymphadenopathy, hepatosplenomegaly, cardiomegaly, or heart murmurs.

NEUROLOGICAL EXAMINATION She was anxious but well orientated and cooperative. The pupils were round, equal, and reactive to light. Ophthalmoscopic examination revealed bilateral early papilloedema. Hypalgesia, hyperreflexia, and an extensor plantar response were present on the right side. In addition, there was weakness of the right lower face. Cerebellar function was normal.

LABORATORY DATA Complete blood count included a haematocrit of $47 \%$ and a total leukocyte count of $7,900 / \mathrm{cu}$. mm. The differential white blood count showed $64 \%$ neutrophils, $30 \%$ lymphocytes, and $6 \%$ eosinophils. Urinalysis and stool examinations were normal. Blcod chemistry studies including fasting blood sugar, blood urea nitrogen, serum electrolytes, calcium, phosphorus, alkaline phosphatase, sulphobromophthalein (Bromsulfalein ${ }^{R}$ ) retention, serum glutamic oxalic and pyruvate transaminases and protein bound iodine were normal. Protein electrophoresis and immunoglobulin electrophoresis were also within normal limits. Two blood and urine cultures were negative for fungus and bacteria. Radiographs of the skull and chest were normal. Brain scan with mercury $^{203}$ (Fig. 1) showed increased uptake of radioactive isotope in the left postero-parietal region. A ventriculogram showed downward displacement of the roof of the lateral ventricle with a shift of the ventricular system from left to right (Fig. 2). Cerebrospinal fluid taken from the right lateral ventricle before the ventriculogram contained 10 lymphocytes and 5 red blood cells/cu. $\mathrm{mm}$, protein of $60 \mathrm{mg} / 100 \mathrm{ml}$, and sugar of $40 \mathrm{mg} / 100 \mathrm{ml}$. An aspiration biopsy through a left postero-parietal trephine site yielded soft semi-liquified brain tissue. Periodic acidSchiff (PAS) stains of the biopsy material revealed budding yeast-like organisms along with many granulomas and multinucleated giant cells. Special stains for acid fast bacteria were negative. Cultures of the cerebrospinal fluid and cerebral tissue yielded Candida organisms. The species was subsequently identified as Candida albicans by the Communicable Disease Centre in Atlanta, Georgia.

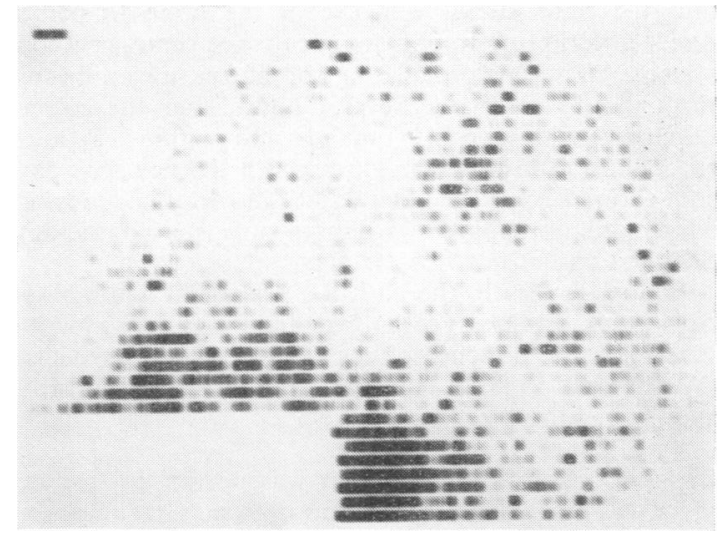

FIG. 1. Brain scan with mercury ${ }^{203}$ (chlormerodrin) showing increased radioactive uptake in the left posteroparietal region.

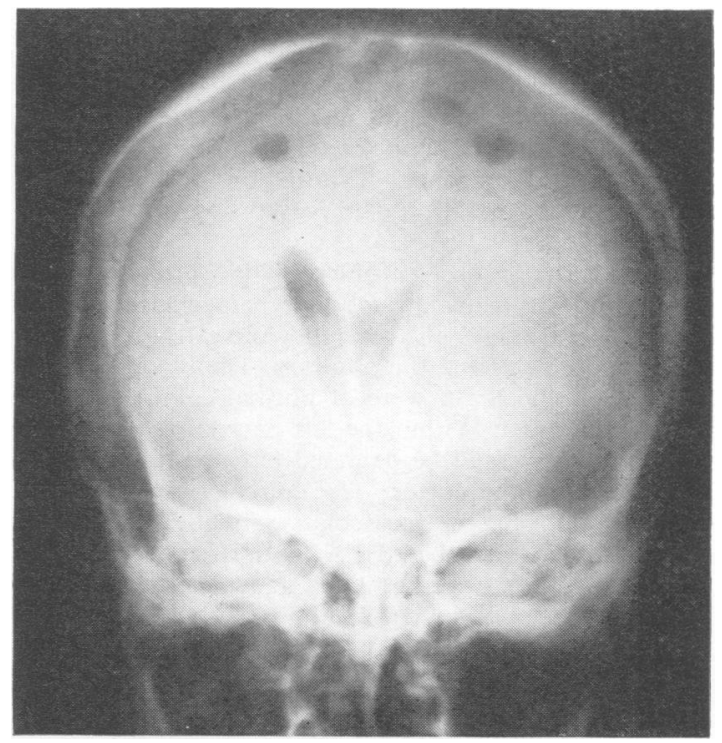

FIG. 2. Posterior-anterior view of the ventriculogram showing the shift from left to right of the ventricular system with downward depression of the roof of the left lateral ventricle.

HOSPITAL COURSE After positive identification of a fungal infection by brain biopsy, intravenous amphotericin B was started with an initial dose of $10 \mathrm{mg}$ and gradually increased to a dose of 30 to $50 \mathrm{mg}$ every other day. By the seventh hospital day she had developed global aphasia and complete right upper extremity paralysis. By the 18th hospital day she had received a total of $430 \mathrm{mg}$ intravenous amphotericin and her blood urea nitrogen had risen to $36 \mathrm{mg} / 100 \mathrm{ml}$. An Ommaya reservoir was inserted 
into the right lateral ventricle of the brain to permit direct injection of amphotericin into the central nervous system. An initial dose of $1 \mathrm{mg}$ amphotericin was injected through this reservoir. Several hours later the patient developed diaphoresis, vomited, and within 12 hours she was in a deep coma. Throughout the next few days she showed signs of increasing intracranial pressure which did not improve with systemic steroid therapy. She died on the 21 st hospital day.

Before her death, the patient's peripheral white blood cells were stained with benzidine nitroprusside to determine the presence of the enzyme myeloperoxidase (Washburn, 1928). Her neutrophils showed positive staining for this enzyme.

GENERAL NECROPSY The heart was normal in size and there was no evidence of valvular disease. The lungs were unremarkable except for a small area of bronchial pneumonia and atelectasis, but the hilar lymph nodes contained several small granulomata. The liver was normal in size, shape, and consistency but microscopic sections revealed several small granulomas which contained positive PAS staining fungal organisms. The spleen weighed $310 \mathrm{~g}$ and contained multiple small, soft granulomas 1 to $4 \mathrm{~mm}$ in diameter in which PAS positive fungal organisms were demonstrated. The kidneys were of normal size but were soft in consistency. Microscopic examination showed embolized fungi in the glomeruli. There was no evidence of fungi on both gross and microscopic examination of the gastrointestinal tract.

NEUROPATHOLOGIC.AL FINDINGS The brain weighed $1,130 \mathrm{~g}$ and was oedematous and hyperaemic throughout. An exudate was present over the convexity and base of the brain and covered the pituitary. The blood vessels at the base of the brain were of normal calibre and were free of atheroma. Within the left parietal region a large fluctuant mass could be palpated but was not visible on the surface of the cortex. The convolutions of the left cerebral hemisphere, particularly in the left parietal region, were widened and the fissures were small. The cerebellar tonsils were herniated and there was notching of the hippocampal gyri bilaterally.
Horizontal sections through the cerebral hemispheres revealed a large ill-defined, soft mass $8 \mathrm{~cm}$ in diameter, in the left mid and posterior parietal region. The mass was filled with yellow necrotic material and in its posterior region a haemorrhage, $3 \mathrm{~cm}$ in diameter, was noted. The mass did not extend to the surface of the cortex, but did invade and obliterate part of the left lateral ventricle. Small multiple haemorrhages could be seen throughout sections of the pons and midbrain.

Microscopic sections of the leptomeninges at the base of the brain revealed an acute inflammatory reaction with infiltration of polymorphonuclear leukocytes, but no $\stackrel{\mathcal{S}}{\rightarrow}$ granuloma or PAS positive fungi were seen. Haematoxylin and eosin stains of sections through the brain abscess showed focal caseation necrosis with multinucleated $\frac{\bar{S}}{\partial}$ giant cells and scattered neutrophilic debris (Fig. 3). $\overparen{\Phi}$ Candida in the form of yeast and mycelia were demonstrated in these areas with the use of PAS stains (Fig. 4).

\section{DISCUSSION}

Candida is an oval, budding, yeast-like fungus which produces a pseudomycelium in culture, tissue, and exudates. The media employed in every $\underset{\omega}{\omega}$ routine bacteriological laboratory are adequate for $\dot{\omega}$ the recovery of Candida from clinical specimenș but the organism grows most readily on Sabourau agar. Candida is gram-positive and is also readity demonstrated by Grocott's methenamine silve technique and the modified periodic acid-Schi

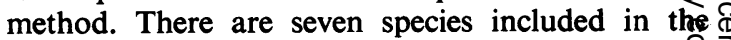
genus Candida, but the most common cause of infection in man is Candida albicans. This organism may be differentiated from the other species $\frac{1}{4}$ fermentation of specific chlamydospores.

CLINICAL FEATURES Candida albicans rarely invades the central nervous system. Our review of the literature has revealed $\mathbf{4 2}$ cases of cerebral candidiasis (see bibliography) since Heller's first case in

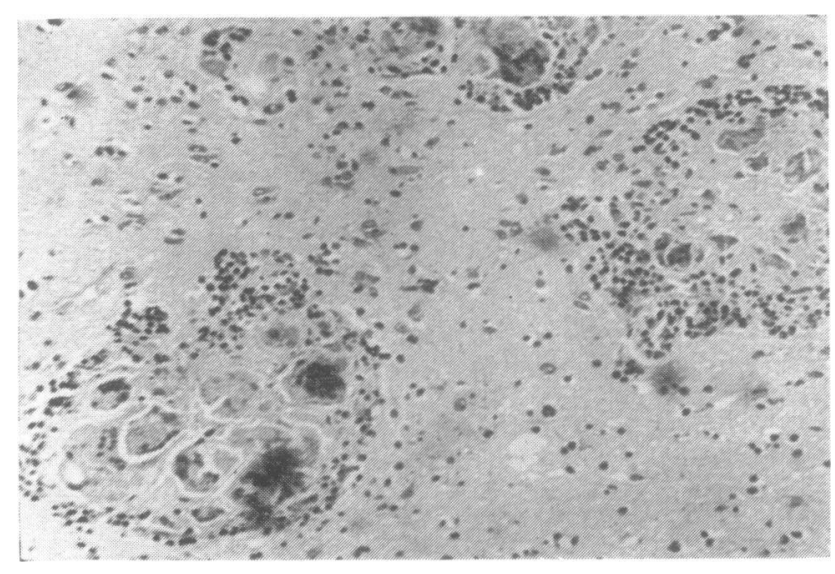

FIG. 3. Section through the brain abscess showing granuloma with multinucleated gianto cells and surrounding polymorphonuclear leuko-ī cytes. Haematoxylin and eosin, $\times 25$. 


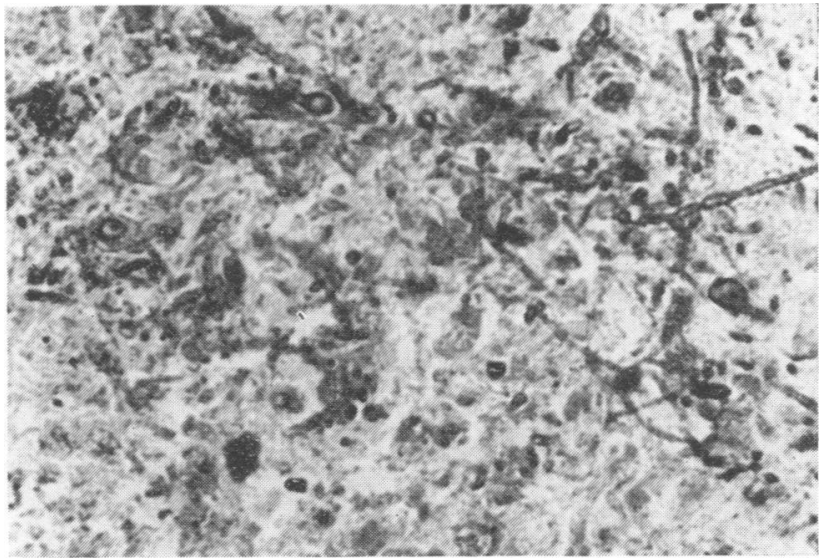

FIG. 4. Candida in yeast and mycelial form within the brain abscess. Periodic acid-Schiff, $\times 100$.

1895. Fifteen of these patients either had abscess or granulomatous involvement of the brain, and 27 had meningitis without extension of the infection to the adjacent parenchyma. Thirty-five patients had one or more antecedent conditions which increased their susceptibility to fungal infections, such as antibiotic therapy, adrenocortical steroid therapy, or severe debilitating illness. In seven patients, however, no demonstrable predisposing factor could be found to account for the central nervous system candidal infection (Miale, 1943; Zimmerman, Frutchey, and Gibbes, 1947; Craig and Gates, 1949; Parrillo, 1950; Levi and Rezza, 1950; Janke, 1957; Vorreith, Bares, Benes, and Vančuř́k, 1961).

In the entire group of 42 , there was a greater than 2 to 1 predominance of men. The age distribution showed one particularly interesting feature. Twelve patients were infants less than 1 month of age. Other authors (Seelig, 1966; Lederer and Todd, 1949) also reported the increased incidence of systemic candidiasis in the newborn infant. In most instances the source of the infection is from the birth canal, and the disease is felt to stem from the fact that newborn infants have immature immune mechanisms. In the remaining 30 patients there were eight in the first decade, three in the second, seven in the third, four in the fourth, two in the fifth, four in the sixth, and two in the seventh decade. The oldest patient was 68 years old.

The cerebrospinal fluid findings are similar to those of pyogenic bacterial meningitis. The cell count ranged from 0 to $22,560 \mathrm{cu}$. $\mathrm{mm}$ (Nalenz and Boese, 1951), with a preponderance of neutrophils. The spinal fluid sugar may be low or normal. The protein is usually elevated and may reach as high as $940 \mathrm{mg} / 100 \mathrm{ml}$. (Ingomar and Terslev, 1964). The spinal fluid cultures were positive for Candida albicans in nearly all the cases of meningitis. In contrast, identification of the fungus in the spinal fluid was more difficult in those patients who had brain abscess without involvement of the meninges. Therefore, the only definitive diagnostic procedure in patients with abscess or granuloma was surgical biopsy. In the four cases (including the present patient) in whom brain biopsy was performed, either by craniotomy or through trephine site, a specimen was obtained and the organism was identified as Candida albicans (Craig and Gates, 1949; Luyendijk, Welman, and Cormane, 1959; Vorreith et al., 1961).

The prognosis in cerebral candidiasis differs depending upon the nature and the site of the infection. DeVita et al. (1966) stated that the survival rate in patients with meningitis before the use of amphotericin B was $68 \%$, and $83 \%$ after the advent of this drug. In our review of the literature, 18 of 27 patients with meningitis survived. In contrast, only one of 16 patients (including the present patient) with brain abscess or granuloma lived more than four months after the diagnosis was made (Luyendijk et al., 1959). There are a number of reasons for the poor prognosis in patients with cerebral involvement. As mentioned above, the cerebrospinal fluid cultures are frequently negative, the symptoms and signs of brain abscess are often vague, and there may be little extracranial fungal involvement to provide a useful clue for the diagnosis. Therefore, most cases of cerebral candidiasis are unsuspected during life or are diagnosed during the terminal stages of the associated illness.

Detailed neurological descriptions have been scarce. As suggested by the pathology, signs and symptoms referable to the cerebral cortex or cerebellum may dominate the clinical picture. In our patient, aphasia, hemiparesis, focal seizure, and papilloedema suggested the presence of an intracranial mass. Headache, photophobia, nuchal 
rigidity, and delirium may dominate the symptoms and signs in patients with meningitis.

PATHOLOGY AND PATHOGENESIS The kidney is the organ most commonly involved in systemic candidiasis and death is usually secondary to kidney failure (Louria, Stiff, and Bennett, 1962). Next affected are the heart, lung, gastrointestinal tract, spleen, and brain in that order (Louria et al., 1962). Candida usually reaches the brain by the haematogenous route and its usual portal of entry into the circulation is through the gastrointestinal tract (Seelig, 1966), although in some cases it may come from the respiratory system or heart (Geiger, Wenner, Axilrod, and Durlacher, 1946). The means by which spores gain access to the circulation depends upon underlying conditions. According to Seelig (1966), surfaces in contact with proliferating organisms are more likely to be penetrated by the fungus when their integrity is compromised. Thus alterations in the mucous membrane surface by inflammation, surgical trauma, local irritation from antibiotics or Candida toxin, facilitate the penetration of the fungus into the blood stream.

Microscopically, the organism provokes inflammation of the affected cerebral or meningeal blood vessels. These vessels subsequently become congested and thrombosis may occur with infarction of surrounding tissue. At the site of cerebral infarction, necrosis, haemorrhage, and infiltration with microglia and macrophages may occur along with proliferation of astrocytes. Fungi can often be seen within the infarcted area. Later, abscess or granuloma formation occur, although frequently these lesions are small and often noted only on microscopic examination. Multinucleated giant cells may be present in the granulomas.

Exactly how the fungi destroy tissue or calls is unknown, but there is evidence that the organism may release a toxin. The exact nature of this toxic substance has not been defined chemically or immunologically. Further information about this substancecan befound in the review by Friedman (1965).

TREATMENT Favourable results have been reported after therapy with iodides. (Bogen and Kessel, 1937; Zimmerman et al., 1947; Rezza, 1950; Emdin and Finlayson, 1954), sulphonamides (Fine, Franklin, and Lieberthal, 1955), streptomycin (Levi and Rezza, 1950; Nalenz and Boese, 1951; Carron and Chavanis, 1954), propylparaben (Gessler and Laux, 1957; Janke, 1957), and nystatin (Debre, Lelong, Mozziconacci, and Robineau, 1957; Luyendijk, Welman, and Cormane, 1959). However, amphotericin $B$ is now the drug of choice in this disease (DeVita, Utz, Williams, and Carbone, 1966).
This drug is a polyene antibiotic which acts by interfering with the function of the cytoplasmic membrane of fungal cells. The current theory is that the antibiotic binds with certain sterols in the cellular membrane causing leakage of cytoplasmic ov contents and impairment of fungal cell metabolism (Utz, 1964). The drug is fungistatic and a total intravenous dose of approximately 2 to $3 \mathrm{~g}$ is necessary for therapeutic benefit.

The patient reported in this paper received 30 to $50 \mathrm{mg}$ intravenous amphotericin B every other day to a total of $430 \mathrm{mg}$. However, despite this therapy, her neurological status worsened while her blood urea nitrogen rose to $36 \mathrm{mg} / 100 \mathrm{ml}$. Consequently an Ommaya reservoir was inserted into the right lateral ventricle of the brain through which amphotericin could be injected. The decision to insert the reservoir was based on the evidence that only small amounts of the drug cross the blood cerebrospinal fluid barrier (Louria, 1958). It was also felt that the reservoir permitted more prolonged and higher peaks of intracerebral amphotericin than would $\underset{\omega}{\omega}$ have been possible with the lumbar or intravenous $\sigma$ route alone. The recommended intraventriculapo $\infty$ dose of amphotericin is 0.3 to $1.0 \mathrm{mg}$ daily or evero $\$$ other day depending upon patient tolerance. Ad 음 initial intraventricular dose of $1.0 \mathrm{mg}$ was adminis tered to our patient.

There seemed to be a causal relationship betweef the intraventricular injection and the patient subsequent worsening neurological status. Micros. $\mathbb{D}$ scopic examination of the meninges revealed at acute meningitis but no evidence of granuloma or $\vec{\theta}$ PAS positive staining fungi. This raises the possibility of a meningitis caused by the amphotericin itself. Chemical meningitis as a result of lumbar intrathecal injections of amphotericin rarely occurs (Spickard, Butler, Andriole, and Utz, 1963), but the incidence of meningitis after intraventricular injections has never been recorded. Perhaps the dosage of the initial injection is an important contributing factor in the formation of the acute meningeal inflammation. It may well be that $1 \mathrm{mg}$ amphotericin was an excessive initial intraventricular dose for our patient.

AETIOLOGY Debilitating disease, antibiotic therapy, and adrenocortical hormones acting either alone or in combination seem to predispose to disseminated candidiasis. There is at present no explanation for this predisposition, but it seems probable that the infection is related in some way to suppression of normal immunity mechanisms.

Occasionally central nervous system candidiasis $N$ occurs in patients in whom no predisposing medication or illness can be found. The aetiology of the 
infection in these individuals is not clear, but it may be related in part to the virulence of the infecting strain of Candida albicans (Louria et al., 1962). The mechanism of tissue localization in these individuals is also uncertain, but there is some experimental evidence that suggests that certain strains and species of Candida have a predilection for brain tissue. Smith and Sano (1933) studied a strain of Candida albicans acquired from the brain of one patient and reported that it was neurotropic when injected into rabbits. Also Louria et al. (1962) showed that certain species of Candida regularly produced central nervous system infection in mice after intravenous injection. However, despite the fact that certain strains and species of Candida seem neurotropic in experimental animals, no conclusions can be drawn concerning the possibility that the course and tissue localization of human candidiasis is related to characteristics of the invading strain of Candida organisms (Louria et al., 1962).

It may also be argued that apparently healthy individuals who develop such dissemination actually suffer from a specific immunological or enzymatic defect which does not ordinarily manifest itself as an impairment in general health. Recently, Lehrer and Cline (1969) discovered that the neutrophils and monocytes of an otherwise healthy patient afflicted with disseminated Candida albicans infection lacked detectable levels of the lysosomal enzyme myeloperoxidase. They concluded that this enzyme was specifically necessary for the killing of Candida organisms by human white blood cells after phagocytosis. However, disseminated candidiasis due to a specific susceptibility engendered by the lack of leukocyte myeloperoxidase is unlikely in our patient, for she had a normal amount of this enzyme in her neutrophils. There is the possibility that our patient lacked another, as yet undelineated, neutrophilic enzyme that is specifically necessary for candidacidial activity.

The author is particularly indebted to Dr. Peritz Scheinberg and Dr. Robert Daroff from the Department of Neurology, University of Miami, for the critical reading of this manuscript. He is also grateful to Dr. John Pfaff and Dr. Alexander Johnson, of Great Falls, Montana, for the pathological studies and neurosurgical assistance.

\section{REFERENCES AND BIBLIOGRAPHY}

Bogen, E., and Kessel, J. (1937). Monilial meningitis. Arch. Path., 23, 909.

Bussolati, C. (1949). Un Caso di Meningoencefalite da Mycotorula. G. Mal. infett., 1, 163-166.

Carron, R., and Chavanis, P. (1954). Meningite a Candida albicans après antibiotherapie prolongée locale et générale. Pediatrie, 9, 387-390.

Casazza, A. R., Duvall, C. P., and Carbone, P. P. (1966). Summary of infectious complications occurring in patients with Hodgkin's disease. Cancer Res., 26, 1290-1296.

Craig, W. M., and Gates, E. M. (1949). Metastatic mycotic abscesses of the brain. Arch. Neurol. Psychiat. (Chic.), 62, 314-321.

Debré, R., Lelong, M., Mozziconacci, P., and Robineau, J. (1957). Les infections à Candida albicans du nourrisson et de l'enfant. Sem. Hôp., Paris, 33, 731-750.

DeVita, V. T., Utz, J. P., Williams, T., and Carbone, P. P. (1966). Candida meningitis. Arch. intern, Med., 117, 527-535.

Emdin, W., and Finlayson, M. H. (1954). Moniliasis of the central nervous system in a child with recovery. South $\mathrm{Afr}$. med. J., 28, 868-871.

Eschwege, J. (1958). Generalized moniliasis with localization in the brain. Arch. Neurol. Psychiat. (Chic.), 79, 250-263.

Fine, J. M., Franklin, D. A., and Lieberthal, A. S. (1955). Mycotic meningitis due to Candida albicans: four year recovery. Neurology (Minneap.), 5, 438-443.

Friedman, L. (1965). Candidiasis (moniliasis) and aspergillosis, in Immunological Diseases, pp. 459-468. Edited by M. Samter and H. L. Alexander. Little, Brown: Boston.

Geiger, A. J., Wenner, H. A., Axilrod, H. D., and Durlacher, S. H. (1946). Mycotic endocarditis and meningitis. Yale J. Biol. Med., 18, 259-268.

Gessler, U., and Laux, W. (1957). Beitrag zur Klinik de Monilia-meningitis. Ärtzl. Wochenschrift, 12, 899-902.

Giessler, G., and Gulotta, F. (1964). Moniliasis des Zentralnervensystems. Zbl. allg. Path. path. Anet., 105, 433-439.

Heller, A. (1895). Beitrag zur Lehre vom Soor. Deutsch. Arch. klin. Med., 55, 123-140.

Ingomar, C. J., and Terslev, E. (1964). Candida albicans meningitis hos en nyfodt: et Tilfaelde Kompliceret med Hydrocephalus. Ugeskr. Lag., 126, 1110-1112.

Janke, D. (1957). Zur serologie der moniliasis. Arch. klin. exper. Derm., 206, 608-614.

Klimowicz, L., Popow, J., and Gorczynska, Z. (1963). Uogólniona grzybica narzạdowa w przebiegu marskošci wạtroby. Pol. Tyg. lek., 18, 64-67.

Kozinn, P. J., Taschdjian, C. L., Pishvazadeh, P., Pourfar, M., and Neumann, E. (1963). Candida meningitis sucessfully treated with amphotericin B. New Engl. J. Med., 268, 881-884.

Lederer, H., and Todd, R. M. (1949). Thrush in infancy. Arch. Dis. Childh., 24, 200-207.

Lehrer, R. I., and Cline, M. J. (1969). Leukocyte myeloperoxidase deficiency and disseminated candidiasis: the role of myeloperoxidase in resistance to Candida infection. J. clin. Invest., 48, 1478-1488.

Lelong, M., Alison, F., Le Tan Vinh, Dao Van Ty, Desmonts, G., and Cabanes, J. (1953). Le muguet généralisé (septicémie à Candida albicans). Ann. Med., 54, 5-21.

Levi, P., and Rezza, E. (1950). Studio di una Mycotorula (Candida) albicans, Agente di una Meningite. Nuovi. Ann. Ig., 1, 404-413.

Louria, D. B., Stiff, D. P., and Bennett, B. (1962). Disseminated moniliasis in the adult. Medicine (Baltimore), 41, 307-337.

Louria, D. B. (1958). Some aspects of the absorption, distribution and excretion of amphotericin B in man. Antibiot. Med., 5, 295-301.

Luyendijk, W., Welman, A. J., and Cormane, R. H. (1959). Candidiasis met intracraniele lokalisatie (neurologische, mycologische en therapeutische aspecten). Ned. T. Geneesk, 103, 2320-2325. 
Marianelli, L. (1967). Su un caso di meningite da candida del lattante trattata con anfotericina_B. Riv. clin. Pediat., 80, 470-476.

Miale, J. B. (1943). Candida albicans infection confused with tuberculosis. Arch. Path., 35, 427-437.

Mietens, C. (1965). Candida albicans-Meningitis im Säuglingsalter und ihre Behandlung mit Amphotericin B. Arch. Kinderheilk., 172, 295-300.

Morris, A. A., Kalz, G. G., and Lotspeich, E. S. (1945). Ependymitis and meningitis due to Candida (Monilia) albicans; report of fatal case of meningitis, with comment on its clinical, bacteriologic and pathologic aspects. Arch. Neurol. Psychiat. (Chic.), 54, 361-366.

Mosberg, W. H., and Arnold, J. G. (1950). Torulosis of the central nervous system: Review of literature and report of five cases. Ann. intern. Med., 32, 1153-1183.

Nalenz, V. P., and Boese, W. (1951). Ueber einen fall von Blastomyceten meningitis. Med. Klin., 43, 1130-1132.

Nezelof,G., and Sarrut, S. (1957). Infections mortelles à candida chez le nouveau-né et le nourrisson: six observations anatomohistologiques. Sem. Hôp., Paris, 33, 2949-2958.

Olmer, J., Payan, H., Casanova, P., Muratore, R., and Serratrice, G. (1957). Mycose à forme cérébrale après antibiothérapie. Presse méd., 65, 1717-1719.

Parrillo, O. J., (1950). Disseminated mycotic disease. J. Amer. med. Ass., 144, 747-749.

Parrillo, O. J., Meiberger, M., and Elston, H. (1962). Candida meningitis complicating Hodgkin's disease: Apparent recovery with amphotericin B therapy. J. Amer. med. Ass., 182, 187-191.

Rezza, E. (1950). Meningite da Mycotorula albicans in Lattante Affetto da Tbc. Miliare Polmonare. Minerva pediat., 2, 587-591.

Roessmann, U., and Friede, R. L. (1967). Candidal infection of the brain. Arch. Path., 84, 495-498.
Seelig, M. S. (1966). The role of antibiotics in the pathogenesis of Candida infections. Amer. J. Med., 40, 887-917.

Smith, L. W., and Sano, M. E. (1933). Moniliasis with meningeal involvement. J. infect. Dis., 53, 187-196.

Spicer, C., Hiatt, W. O., and Kessel, J. F. (1948). Candida albicans and Cryptococcus neoformans occurring as infective agents in an 8 year old boy. J. Pediat., 33, 761-769. T

Spickard, A., Butler, W. T., Andriole, V. T., and Utz, J. P. (1963). The improved prognosis of cryptoccocal meningitis with amphotericin B therapy. Ann. intern. Med., 58, 66-83.

Utz, J. P. (1964). Amphotericin B toxicity. Combined clinical staff conference at the National Institutes of Health. Ann. intern. Med., 61, 334-354.

Utz, J. P., Treger, A., McCullough, N. B., and Emmons, C. W. (1959). Amphotericin B: intravenous use in 21 patients with systemic fungal diseases. In Antibiotics Annual 1958-1959; Proceedings of the 6th Annual Symposium on Antibiotics. Edited by H. Welch and F. Marti-Ibanez. Medical Encyclopedia: New York.

Vacher, L. B., and Guernica, A. (1963). Moniliasis generalizada en un recién nacido. Rev. Cuba Pediat., 35, 3-10.

Verger, P., Guillard, J. M., and Boisseau, M. (1964). Meningite à Candida albicans đu nourrisson traitée par l'amphotericine B Guerison. Arch. franc. Pediat., 21, 569-578.

Von Hibler, E. (1904). Ueber einen Fall von Pyäemie mit Soorinfection. Zbl. Bakt., I. Abt. Ref., 36, 505-519.

Vorreith, M., Bareš, L., Beneš, V., and Vančuřík, J. (1961). Kandidóza Centrálního Nervového Systému Rozpoznana ci Bioptickým Vyšetřením. Čas. Lék. Čes., 100, 966-971.

Washburn, A. H. (1928). Combined peroxidase and Wright's stain for routine blood smears. J. Lab. clin. Med., 1 p 246-250.

Zimmerman, L. E. (1955). Fatal fungus infections comp cating other diseases. Amer. J. clin. Path., 25, 46-65.

Zimmerman, S. L., Frutchey, L., and Gibbes, H. (1948) Meningitis due to Candida (Monilia) albicans with recover. J. Amer. med. Ass., 135, 145-147. 